\title{
Why are Muslim Bans Wrong? Diagnosing Discriminatory Immigration Policies with Brock's Human Rights Framework*
}

\author{
Matthew Lindauer \\ Brooklyn College, City University of New York
}

Forthcoming in Res Publica

\begin{abstract}
In the course of presenting a compelling and comprehensive framework for immigration justice, Brock (2020) addresses discriminatory immigration policies, focusing on recent attempts by the Trump administration to exclude Muslims from the U.S. (the 'Muslim ban'). This essay critically assesses Brock's treatment of the issue, and in particular the question of what made the Muslim ban and similar policies unjust. Through examining these issues, further questions regarding the immigration justice framework on offer arise.
\end{abstract}

\section{Gillian Brock's Justice for People on the Move: Migration in Challenging Times} (hereafter $J P M$ ) is an important contribution to the political philosophy of immigration. It covers a great deal of practical ground, doing the painstaking work of looking carefully at the empirical reality of global migration, keeping relevant facts close at hand with each philosophical step taken. Despite this difficult philosophical task, the book is written in non-technical language throughout that the general public and policymakers considering such issues can understand, engage with, and potentially be persuaded by (and there is much to be persuaded by in the book). $J P M$ strikes an unusual balance between the theory and practice of migration policy that is deep on both sides and, though largely avoiding methodological topics, exemplifies how theory and data can inform one another. It is humane and compassionate towards the world's most vulnerable migrants, refugees, while nonetheless seeking to understand the misguided thinking behind the attraction of anti-immigrant rhetoric for many ordinary people, as well as whose interests roadblocks in the ways of progress on migration justice serve.

While I greatly admire what Brock has done in $J P M$, I have some questions and concerns about its account of what makes discriminatory policies like the recent 'Muslim ban' initiated by the Trump administration in the U.S. unjust, and the tight relationship this account has with a practice-based conception of human rights. Needless to say, I agree with Brock's assessment that Muslim bans and migration policies that employ invidious forms of discrimination are wrongful, although perhaps certain forms of positive discrimination on the basis of religion are permissible (a smaller point that I will return to). Where we diverge most, I think, is on what may be aptly labeled the 'diagnostic question,' the question of what makes such policies unjust.

\footnotetext{
* I would like to thank Christian Barry, Serene Khader, Daniel Putnam, and an anonymous reviewer for helpful comments.

${ }^{1}$ In using this label, I have been influenced by Elizabeth Anderson's The Imperative of Integration (2010). To borrow Anderson's medical analogy, as a doctor diagnoses the patient and thereby determines what is wrong with them, the philosopher can also diagnose an injustice by determining what is wrong with it, i.e. what makes it wrong. While the label is convenient for my purposes here, it is worth noting that Anderson has something broader in mind with her focus
} 
In my estimation, there are several holes in the answer to this question given in Chapter 4 of $J P M$. After examining a series of issues with the answer that Brock provides regarding Muslim bans, I pause to consider what the motivation may be for such an account, informed by the rest of the content of the book. In particular, relying on a practice-based account of HR to answer the diagnostic question seems undermotivated, offering an implausible basis for concluding that Muslim bans are wrong. I then offer what I intend to be helpful remarks on how the project's use of the practice-based account of HR could be reframed to avoid some of the objections that I raise, and better shore up the project against criticism from a more morally-focused approach to diagnosing the wrongness of Muslim bans and other discriminatory immigration policies.

\section{Preliminaries}

$J P M$ presents a comprehensive framework for thinking about migration justice from both a theoretical and policy perspective. Before getting to the critique of Brock's diagnosis of Muslim bans and other discriminatory immigration policies, I'd like to put some preliminaries in place regarding the normative grounding that Brock provides for her framework in the book.

\section{Self-Determination, Legitimacy, and Human Rights}

The crux of the normative grounding of the approach is presented in Chapter 3, where Brock argues for a set of legitimacy conditions that states must meet in order to have the moral right to self-determination. Part of what will be of interest in this approach for immigration theorists is that the right to self-determination, Brock notes, carries along with it some amount of discretion in setting and implementing immigration policies. This right has been appealed to by prominent theorists arguing for the permissibility of a fairly wide range of immigration restrictions, including Michael Walzer (1983) and Christopher Heath Wellman (2008). If it turns out that certain types of immigration restrictions, such as those that involve invidious forms of discrimination, are incompatible with these preconditions for the right to self-determination, Brock's argument will undercut the permissibility of these types of restrictions upstream, so to speak.

Where self-determination is grounded in legitimacy, the three legitimacy conditions (LCs) that Brock sets out are grounded in human rights. LC1 holds that states must respect their own citizens' human rights in order to exercise power legitimately - it is, in this sense, an internal requirement of state legitimacy. LC2 holds that states must be part of a legitimate state system in order to exercise power legitimately. And lastly, LC3 is the claim that states have positive obligations to participate in the cooperative project of contributing to and upholding a justified state system, which Brocks refers to as a contribution requirement.

According to Brock, there are wide-ranging implications of failure to comply with these three requirements, including the potential undermining of a state's right to control its own borders, and the potential undermining of the legitimacy of the state system itself. Brock is in line with 'fellow travelers' Joseph Carens (2015), David Owen (2016), and Christopher Bertram (2018) whose views on immigration justice depend on the idea of a legitimate state system and

on 'diagnosis' in non-ideal theory, including determining the causes of a given problem and also what to do about it, given our motivational and cognitive deficiencies. Still, the question is close enough to Anderson's approach that the connection is worth mentioning. 
failure of that system as calling the rights of states to exclude into question. ${ }^{2}$ But crucially for Brock, the legitimacy of states and the state system must be seen through this three-layered account involving internal legitimacy, the legitimacy of the overall state system, and what states are and are not doing to uphold a legitimate state system.

In defining legitimacy at each of these levels, Brock leans heavily on the notion of human rights, and in particular a practice-based account of human rights of the kind developed by Charles Beitz (2011). On this view, human rights not grounded in rights as moral entitlements that belong to all human beings in virtue of facts about human nature (Griffin 2009). Nor are human rights to be understood as the object of an overlapping consensus among different societies (Ignatieff 2003). Rather, the practice-based account of human rights centers on the distinctive normative practice that has emerged in our contemporary world at the international level. This practice originates in the post-war period with the 1948 adoption of the Universal Declaration of Human Rights (UDHR). It has further developed through the creation of other international treaties, human rights courts and other regional and international bodies, through the work of several non-governmental organizations that monitor human rights compliance, and with the broadening of commitment to the practice by states and individuals. On this view, we are supposed to understand the concept of a human right by grasping the role that the concept plays within this recent historical practice (Beitz 2011, p. 8). No deeper normative grounding is needed than the practice itself and the role of the concept of a human right within it to understand the basis for human rights as generating obligations for states. These obligations center on protecting "urgent individual interests against certain predictable dangers ('standard threats')" (Beitz 2011, p. 109), and the failure to discharge them is a matter of international concern that can give outside agents, such as other states, license to intervene or take other actions. Brock aims to show how requirements in particular areas of migration policy fall out of LC1, LC2, and LC3, with a practice-based human rights interpretation of legitimacy. ${ }^{3}$

\section{The Muslim Ban and Brock's Conditions of Legitimacy}

When examining the Muslim ban in the U.S. and other discriminatory immigration policies, Brock aims to use each of the legitimacy conditions to show that these policies are unjust and contrary to human rights. ${ }^{4}$ She begins by attempting to show that these policies violate LC1, the internal requirement, which again holds that states must respect their own citizens' human rights. She claims that 'combating intolerance and discrimination has been one of the top priorities of our international human rights regime since its founding' (Brock 2020, $p$. 77), and invokes a set of UN treaties and resolutions to support this claim. The case starts with Article 18 of the UDHR, which states that everyone has the right to 'freedom of thought, conscience, and religion' and the right to change their beliefs and practice as they wish in public or private. It moves on to Articles 2, 4, 18, 20, 26, and 27 of the International Covenant on Civil and Political Rights (ICCPR), which rule out discrimination on the basis of 'race, colour, sex,

\footnotetext{
2 Though perhaps there are additional reasons why they are not morally permitted to exclude, as one might glean from, e.g., Carens' other arguments for open borders (Carens 1987).

${ }^{3}$ This is generally true of her account, although sometimes other moral or prudential commitments are brought to bear on particular issues.

${ }^{4}$ Brock gives a helpful overview of how the Muslim ban in the U.S. was gradually implemented in Chapter 4.
} 
language, religion, political or other opinion, national or social origin, property, birth or other status' (Article 2), coercion to adopt religious beliefs (Article 18), and cover related matters such as incitement to discrimination, hostility, and violence (Article 20), equality under the law (Article 26), and the right to enjoy one's own culture, religion, and use own's own language (Article 27). ${ }^{5}$ Brock also invokes the Declaration on the Elimination of All Forms of Intolerance and of Discrimination Based on Religion or Belief and the International Convention on the Elimination of All Forms of Racial Discrimination (ICERD). The case is strong that, as far as these HR documents go on their own, a Muslim ban violates the rights of citizens who are Muslims. This sort of line of criticism has been developed by other theorists, starting with Michael Blake (2005), ${ }^{6}$ but Brock's emphasis on human rights as the source of the critique is a distinctive and important avenue for exploring what is wrong with discriminatory immigration policies like the Muslim ban.

Before moving on to the other legitimacy conditions, it is worth noting that the U.S.'s stance towards some HR documents, such as the ICCPR and ICERD, is shakier than one might like. This is especially troubling if one wants to lean on the fact that, since commitment to these documents is voluntary, a state is breaking rules it already signed up for when violating components of the HR consensus, as Brock sometimes does. ${ }^{7}$ While the U.S. Senate ratified the ICCPR, it did so subject to 'Reservations, Understandings, and Declarations (RUDs).' One of these qualifications was that the ICCPR does not authorize actions or legislation that would restrict the Constitutional right to free speech, which Trump's remarks presumably fall under. The RUDs also note that Article 2 and Article 26 do not go beyond the U.S. Constitution's existing protections, and that distinctions 'based upon race, color, sex, language, religion, political or other opinion, national or social origin, property, birth or any other status' are permitted when 'such distinctions are, at minimum, rationally related to a legitimate governmental objective.' Of course, the Muslim ban did not serve a legitimate governmental objective, but this is what the Trump administration asserted as a defense of the policy, and the U.S. Supreme Court narrowly upheld the proclamation on the grounds that it was supposedly based on the legitimate purpose of protecting national security. While no such legitimate purpose was served by the Muslim ban, and as Brock emphasizes, the U.S. is made less safe by such policies and other forms of discrimination (Chapter 8), the U.S. has carved out legal exceptions that make the standing of discriminatory policies, on legal grounds alone, at least ambiguous. The ICCPR is also treated as not 'self-executing,' which means that it lacks some legal significance within the U.S. and limits the ability of persons to bring suits in a court of law

\footnotetext{
${ }^{5}$ Article 4 focuses on the right of states in emergency situations to derogate from their obligations under the ICCPR to the extent required so long as this doesn't involve discrimination 'solely on the ground of race, colour, sex, language, religion or social origin.' Article 18 also includes a clause noting that freedom of religion is subject to limitations 'as are prescribed by law and are necessary to protect public safety, order, health, or morals or the fundamental rights and freedoms of others.'

${ }^{6}$ Wellman claims that while it may be the best available justification, he does not find the critique of discriminatory immigration policies on grounds of domestic justice fully satisfactory (Wellman and Cole 2011, pp. 149-50). I instead develop the critique from domestic justice in an argument against the traditional state sovereignty view in (Lindauer 2017).

${ }^{7}$ See, e.g., (Brock 2020, pp. 87, 196, 223-4).
} 
with the ICCPR as their basis. ${ }^{8}$ In the case of the ICERD, the U.S. also regards the Convention as not self-executing, and along with a number of other states, only interprets it as affirming obligations already within its own constitution. I point to these qualifications not to make a strong case against Brock's approach, but to sound a note of caution in treating the U.S.' commitment to these requirements as strong and fully consistent with what may be the broader spirit of each HR convention. As I will emphasize in the next section, we might wonder whether Brock should primarily appeal to these conventions, as opposed to appealing directly to the harms and other wrongs that discriminatory policies involve.

After addressing LC1, Brock considers the ways the Muslim ban violated LC3, the requirement that legitimate states contribute to and uphold a justified state system. She claims that principles undergirding this requirement 'embody the most basic commitments to the animating ideas and practices governing human rights today' (Brock 2020, p. 83). These principles include (i) maintaining an ethos that is conducive to respect for human rights, and crucially the idea that everyone deserves dignified and respectful treatment qua human being (the 'Ethos Requirement'), (ii) a commitment to accountability and practices that foster it (the 'Accountability Requirement'), (iii) not promoting arrangements in which respect and protection of people's human rights will be significantly worsened, all else being equal (the 'Constraint Against Worsening'), and (iv) showing appropriate international concern as required by the practice of human rights, and acting when one is the agent capable and placed appropriately to have sufficient reason to do so (the 'Commitment to Action Under Relevant Circumstances'). Brock focuses on (i) and (ii), and briefly touches on (iii) and (iv). Because my main concerns do not depend on these contrasts, I will only discuss Brock's case grounded in LC3 briefly.

In violation of LC3(i), Muslim bans contradict the spirit and ethos of human rights. As Brock states, '[e]very person deserves equal respect and deserves to have their application to be admitted to a country given genuine and proper consideration' (2020, p. 83). For Brock, banning people based on religion, race, or national origin fails to treat each person as deserving fair consideration. She mentions that a critic may respond that a waiver system accompanying a Muslim ban, as the U.S. created but failed to properly implement, could sidestep this problem, by considering individual cases on their merits. Brock notes that the U.S.' waiver system was mere window-dressing intended to deflect criticism, and that in reality people's claims were not evaluated on their merits. In response, one might wonder whether the Muslim ban would have passed the Ethos requirement if a waiver system had been properly implemented.

In terms of the Accountability requirement, the Muslim ban also fails, in virtue of not being adequately justified to the international community, including Muslims around the world and nations where they live. The reaction of countries around the world, Brock notes, was to condemn the ban in general. This suggests that the Accountability requirement, understood in terms of giving a proper justification, was not met. As mentioned, Brock also makes the case that Muslim bans worsen commitment to the practice of human rights (iii), for instance by increasing the ammunition available to extremists looking to promote violence, and that agents that could take action to avoid implementing the Muslim ban (iv), i.e. the U.S. Government and the Trump administration's many institutional enablers (perhaps including the majority on the U.S. Supreme Court), failed to do so.

${ }^{8}$ For a helpful overview, see (Lynch 2020). Also see the American Civil Liberties Union (ACLU) FAQ page on the ICCPR (https://www.aclu.org/other/faq-covenant-civil-politicalrights-iccpr). 
On all of these grounds, Brock argues, the U.S. Muslim ban and similar policies contradict the international practice of human rights, and are impermissible for states to implement for this reason. ${ }^{9}$ I now turn to my concerns about this way of diagnosing the wrongness of such policies, before concluding with a suggested way forward for Brock's account.

\section{Principal Objections}

As I have noted, the main normative grounding for Brock's argument against Muslim bans and similar discriminatory immigration policies is a practice-based account of human rights. I will now raise a series of points against this way of grounding the argument and the answer to the 'diagnostic question,' the question of what makes the Muslim ban and similar policies morally wrong, that it provides. These points raise concerns about Brock's reliance on a practice-based account of human rights throughout the book. I do not ultimately think that this foundation, or something like it, must be absent from the book, and will spell out a motivation for it that is consistent with some of what is most original and important about the book's overall project. But the points against the account in this case suggest that, where the practice of human rights is invoked, for certain theoretical purposes at least, it will still be unavoidable as a matter of normative grounding to get down to moral brass tacks.

The first point against Brock's way of addressing the diagnostic question in the case of Muslim bans is that the account has difficulties diagnosing similar discriminatory immigration policies that predate the human rights practice. While there is, of course, some disagreement about when thinking about human rights began, Brock makes use of the idea that combating discrimination has been a top priority of the international human rights regime 'since its founding' (2020, p. 77). Yet the case that kicked off the philosophical literature on discriminatory immigration policies that Brock is entering into is that of the 'White Australia' policy, in particular in Chapter 2 of Michael Walzer's Spheres of Justice (1983). Walzer famously argued that the White Australia policy, a racist policy of excluding non-whites from Australia implemented in 1901 soon after Australian federation, was morally permissible with the qualification that 'White Australia could survive only as Little Australia' (Walzer 1983, p. 47). That is, as long as unused land is made available to people seeking to create another state, it is fully permissible for a state to exercise its self-determination by excluding prospective immigrants on the basis of race. Walzer's case has remained a lightning rod in the literature, with later theorists responding to Walzer's initial arguments nearly any time the question of discriminatory immigration policies arises in analytic political philosophy. Notably, the Universal Declaration of Human Rights (UDHR) would not exist for forty seven years when the White Australia policy was implemented. Similarly for other policies that theorists thinking about discriminatory immigration policies have had to theorize about, such as the American 'Chinese Exclusion Act,' signed by President Chester A. Arthur in 1882, predating the UDHR by sixty six years. If we take the UDHR and period following World War II more generally to signify the founding of the international human rights regime, as Beitz (2011) and Brock (2020, pp. 43-4) suggest they do, the question arises, what to say about pre-practice violations of the

\footnotetext{
${ }^{9}$ Brock also notes that when states fail to meet the requirements of LC1 and LC3, they threaten the legitimacy of the state system as a whole and make a legitimate state system harder to achieve, thereby violating LC2 (Brock 2020, pp. 65, 76-7).
} 
practice's norms? On a straightforward reading it would appear that the practice-based account cannot diagnose these immigration policies, which bear striking similarity to the Muslim ban in their discriminatory intent and content, as moral wrongs on its own. Some other normative framework would have to be brought in to explain why the White Australia policy and Chinese Exclusion Act were wrong, and this raises the question whether the practice-based account really is the best normative grounding for diagnosing the wrong of Muslim bans. This a challenge both from extensional adequacy - covering all of the relevant cases - and consistency - showing that a consistent justification can be applied to similar cases. We should expect a theory to cover and unify these similar types of discriminatory immigration policies under the same moral diagnosis.

On a less straightforward reading, perhaps we can interpret Brock as holding that while the international human rights regime itself did not exist when these other wrongful policies were in place, the practice was somehow nascent at the time. Perhaps even since the Enlightenment, provisional norms of the human rights practice that we now have in place have existed and had some normative force. Kant makes this sort of claim about provisional duties to anticipate a just state in the Metaphysics of Morals (1996), and perhaps states were analogously responsible for fulfilling duties that anticipated the human rights practice that was formally founded in the mid$20^{\text {th }}$ Century. In that case, the practice-based account could potentially still say that such policies were wrong, in that they violated the provisional norms of an emerging practice of human rights.

However, it's not clear to me that such an approach is a plausible one to take. First, it is at odds with Brock's statements throughout the book that at least a significant amount of the normative force of the human rights regime comes from the fact that its commitments have been voluntarily taken up by states in the form of ratifying actual conventions and treaties. Second, even putting this issue to the side, there is a question how such an approach would treat the comparative moral significance of violations of provisional norms versus violations of actual norms that have been voluntarily agreed to. It seems natural to think that the norms of the actual practice, which are again voluntarily acceded to in the case of human rights, carry greater normative force than provisional norms. Yet the Chinese Exclusion Act and Muslim ban, at least to me, seem to be just as morally wrong as one another, and there is pressure from consistency in finding a unified account of why that is the case. ${ }^{10}$

My second concern about Brock's answer to the diagnostic question is that something must be said about whether it is permissible for states that haven't signed and ratified the UDHR and other HR documents to implement discriminatory immigration policies. For instance, Saudi Arabia did not vote for the UDHR when it was adopted by the UN General Assembly, with the stated reservation that its call for freedom of religion was incompatible with the precepts of Islam (many other Muslim-majority countries had no such reservations). Saudi Arabia is also a party to only three human rights treaties. ${ }^{11}$ Human rights abuses are well-documented and common in the country, yet if Saudi Arabia has not voluntary participated in the practice of HR, are there normative grounds for showing that such violations are moral wrongs?

Brock addresses states that aren't signatories to HR treaties in a footnote in Chapter 7, where she says that in these cases 'the same principle applies but alternative channels for

\footnotetext{
${ }^{10}$ Regarding these policies as just as morally wrong as one another is entirely compatible with thinking that we should sometimes judge people in the past more leniently than our contemporaries. I am grateful to an anonymous reviewer for raising this point.

${ }^{11}$ These are the Genocide Convention, the Slavery Convention and the Supplementary Convention on the Abolition of Slavery.
} 
communicating the need for improved performance must be sought. But since 98 percent of states have adopted, endorsed, and/or ratified one or more human rights conventions, and these all have follow-up and review processes, these and other channels will provide relevant further opportunities for such constructive criticism and dialogue.' ${ }^{12}$ This may be correct as a practical matter - we can try to persuade states to uphold their HR commitments even if they are not signatories to the particular documents being invoked, especially if they have signed at least some HR documents. But this still leaves aside the normative question of what makes such violations wrong other than the fact of having violated a voluntary agreement when such agreements are absent.

Suppose that the Kingdom of Saudi Arabia announces in public that it will deny visas to Jewish people, as has sometimes been the case, although the government typically states that the restriction only applies to Israeli passport holders. How should we diagnose what is wrong with such a policy using Brock's framework? We cannot argue that Saudi Arabia has committed to the UDHR and other treaties that Brock cites in ruling out the U.S. Muslim ban. We might try to argue that because Saudi Arabia has signed three other conventions, they are somehow committed to the practice of human rights as a whole. This response, however, seems not to take their refusal to vote for the UDHR and sign other HR documents seriously.

More generally, the practice-based account seems to give an implausible diagnosis of what is wrong with discriminatory immigration policies, which is brought out by reflection on states that haven't committed to the UDHR or other relevant HR treaties. These states wrong prospective immigrants if they ban them on the basis of characteristics like religion, ethnicity, nationality, race, gender, sexual orientation, gender identity, or other statuses because they treat these persons as less than equal human beings, denying them equal respect and dignity. Treating all human beings with equal respect and dignity may be the spirit and ethos of human rights, as Brock states, but it isn't the practice itself. As Christian Barry and Nicholas Southwood note in a more general criticism of practice-based accounts of human rights, these accounts '[elide] the important distinction between human rights and their proper institutionalization' (2011, p. 381). If we cannot appeal to anything but the human rights practice itself in answering the diagnostic question with respect to discriminatory immigration policies, it seems like we have an implausible diagnosis, grounded in contingent features of the practice rather than the moral reality that the practice is supposed to respond to.

A third point, which bears on the need for a moral grounding in our diagnosis of the Muslim ban and similar policies, is that the question whether we can 'defensibly enact policy that discriminates on the basis of religion' (Brock 2020, p. 64) should be sensitive to a difference between at least two types of discrimination. Negative discrimination is discrimination against persons on the basis of group membership or some other characteristic, whereas positive discrimination is discrimination in favor of a person on some such basis. Of course, positive discrimination is sometimes merely window-dressing for negative discrimination. Indeed, the National Origins Formula in the U.S. was sometimes given the public justification of affirming the culture already present in the U.S., rather than discriminating against the citizens and noncitizens who were negatively affected by immigration quotas. But in other cases, it seems permissible, or at least far less problematic, if at all, to give special treatment to some groups for particular reasons that in no way treats other groups as inferior. For instance, suppose that a multicultural society knows that Christians around the world are experiencing discrimination,

12 Brock (2020), p. 165, note 63. 
and has a sizeable Christian population. If for some period of time, that society gave preferential treatment to Christians applying for visas, it's not obvious that this implies that Muslim citizens or non-citizens are regarded as inferior, unless perhaps Muslims around the world were also being discriminated against and this was being ignored. ${ }^{13}$ Preferring one, under some circumstances, in no way impugns the status of another. Yet casting the question in terms of whether immigration policy can permissibly discriminate on the basis of particular qualities ignores this fact. Notably, the difference between negative and positive discrimination is given a plausible explanation by referring to a directly moral notion, expressive disrespect. While I don't have the space to go into it in detail here, in other work I have developed a framework for understanding how immigration policies express attitudes for persons within and outside a society's borders at the same time when these persons are members of a group (Lindauer 2017). The question, then, is what kinds of attitudes, as well as effects, are a part of a policy of negative discrimination as opposed to positive discrimination. But assessing these attitudes and effects requires us to go beyond the practice of human rights, instead considering what moral features the practice of human rights should respond to.

\section{Concluding Remarks and a Potential Way Forward}

As I noted at the start of this essay, Justice for People on the Move is an important book, admirably combining new theoretical insights in political philosophy with a keen focus on emerging trends in global migration. I have raised a set of criticisms of one aspect of the book's project, its diagnosis of the wrongness of the Muslim ban and other discriminatory immigration policies. I would like to close the essay with a brief suggestion for how Brock can reshape the framework's approach to these policies, and perhaps other diagnostic questions as they arise, without giving up what is most central to and novel about the project.

As I have shown, Brock's take on the diagnostic question with respect to discriminatory immigration policies, the question that other theorists in the literature have been interested in with respect to these policies, is vulnerable to a number of objections. But given the practical focus of Brock's immigration justice framework in the book, and its aspiration to provide a theoretical basis for convergence on the Global Compact for Safe, Orderly and Regular Migration, Brock may be better off avoiding defending any particular answers to diagnostic questions regarding types of immigration policies, a strategy that bears similarity to Rawls' "method of avoidance."14 Even philosophers who agree that various discriminatory immigration policies are wrong disagree about the diagnoses of their wrongness. With respect to diagnostic questions like this one, Brock can embrace the view that the practice-based account of human

${ }^{13}$ Of course, other factors will matter in determining whether a particular way of giving preferential treatment to certain visa applicants is morally acceptable. For instance, a state arguably cannot deny visas to the spouses of non-Christian citizens, or create inordinately long wait times for them, in the course of giving preferential treatment to Christian visa applicants. The point here is that the fact of preferential treatment for certain visa applicants itself need not involve the objectionable treatment of any citizens or non-citizens. I am grateful to an anonymous reviewer for suggesting that I clarify this point.

${ }^{14}$ Rawls $(1985,1993)$. However, as I suggest below, this move does not commit Brock to bringing other parts of the Rawlsian apparatus on board, such as the notion of overlapping consensus. 
rights can play a coordinating role between theorists, citizens, and states who will disagree about what makes these policies wrong, but who will have to come together in rejecting the permissibility of these policies. The human rights framework and Global Compact for Migration can give guidance and assurance to individuals and institutions that disagree about ultimate normative groundings. Notably, this move does not commit Brock's framework to any deeper role for the notion of inter-state agreement or overlapping consensus in international justice. The framework can simply pivot towards treating the practice of human rights not as the ultimate normative grounding for diagnosing the wrongs of any particular policies, but instead as the best ground for coordinating the commitments and actions of states with respect to the permissible terms of migration policy.

Justice for People on the Move represents an important step forward in the political philosophy of immigration. I am grateful to have had the chance to reflect on this timely book, and I hope that my criticisms and suggestions make some small contribution towards strengthening this deeply important and practically relevant project.

\section{References}

American Civil Liberties Union (ACLU) FAQ on the International Covenant on Civil and Political Rights, available at: https://www.aclu.org/other/faq-covenant-civil-politicalrights-iccpr

Anderson, Elizabeth. 2010. The Imperative of Integration. Princeton, NJ: Princeton University Press.

Barry, Christian, and Nicholas Southwood. 2011. What Is Special About Human Rights? Ethics \& International Affairs 25(3): 369-383.

Beitz, Charles R. 2011. The Idea of Human Rights. Oxford: Oxford University Press.

Bertram, Christopher. 2018. Do States Have the Right to Exclude Immigrants? Cambridge, UK: Polity Press.

Blake, Michael. 2005. Immigration. In A Companion to Applied Ethics, ed. R. G. Frey and Christopher Heath Wellman, 224-37. Malden, MA: Blackwell Publishing.

Brock, Gillian. 2020. Justice for People on the Move: Migration in Challenging Times. Cambridge, UK: Cambridge University Press.

Carens, Joseph H. 1987. Aliens and Citizens: The Case for Open Borders. The Review of Politics 49(2): 251-273.

Carens, Joseph H. 2015. The Ethics of Immigration. Oxford: Oxford University Press.

Declaration on the Elimination of All Forms of Intolerance and of Discrimination Based on Religion or Belief, available at: https://www.ohchr.org/EN/ProfessionalInterest/Pages/ ReligionOrBelief.aspx

Global Compact for Safe, Orderly and Regular Migration, available at: https://www.un.org/en/ga/search/view doc.asp?symbol=A/RES/73/195

Griffin, James. 2009. On Human Rights. Oxford: Oxford University Press.

Ignatieff, Michael. 2003. Human Rights as Politics and Idolatry. Ed. Amy Gutmann. Princeton: Princeton University Press.

International Convention on the Elimination of All Forms of Racial Discrimination (ICERD), available at: https://www.ohchr.org/en/professionalinterest/pages/cerd.aspx

International Covenant on Civil and Political Rights (ICCPR), available at: 
https://www.ohchr.org/EN/ProfessionalInterest/Pages/CCPR.aspx

Kant, Immanuel. 1996. The Metaphysics of Morals. Edited by Mary J. Gregor. Cambridge Texts in the History of Philosophy. Cambridge, UK: Cambridge University Press.

Lindauer, Matthew. 2017. Immigration Policy and Identification Across Borders. Journal of Ethics and Social Philosophy 12(3): 280-303.

Lynch, Timothy E. 2020. The ICCPR, Non-Self-Execution, and DACA Recipients' Right to Remain in the United States. Georgetown Immigration Law Journal 34: 323-404.

Owen, David. 2016. In Loco Civitatis: On the Normative Basis of the Institution of Refugeehood and Responsibilities for Refugees. In Migration in Political Theory, ed. Sarah Fine and Lea Ypi, 269-290. Oxford: Oxford University Press.

Rawls, John. 1985. Justice as Fairness: Political not Metaphysical. Philosophy and Public Affairs 14(3): 223-251.

Rawls, John. 1993. Political Liberalism. New York: Columbia University Press.

Universal Declaration of Human Rights (UDHR), available at: https://www.ohchr.org/EN/UDHR/Documents/UDHR_Translations/eng.pdf

Walzer, Michael. 1983. Spheres of Justice: A Defense of Pluralism and Equality. New York: Basic Books.

Wellman, Christopher Heath. 2008. Immigration and Freedom of Association. Ethics 119(1): 109-141.

Wellman, Christopher Heath, and Phillip Cole. 2011. Debating the Ethics of Immigration: Is There a Right to Exclude? Oxford: Oxford University Press. 